\title{
Tissue Culture of Cat Whiskers (Orthosiphon stamineus)
}

\author{
Totik Sri Mariani ${ }^{1 *}$, Elfahmi ${ }^{1}$, Yesi Gusnelti ${ }^{1}$ and Hiroshi Miyake ${ }^{2}$ \\ ${ }^{1}$ Biosciences and Biotechnology Research Centre, Institut Teknologi Bandung, Indonesia \\ ${ }^{2}$ Graduate School of Bio agricultural Sciences, Nagoya University, Japan
}

Submission: January 20, 2018.; Published: February 21, 2018

*Corresponding author: Totik Sri Mariani, Biosciences and Biotechnology Research Centre, Institut Teknologi Bandung, Indonesia,

Email: totiksrimariani@yahoo.com

\begin{abstract}
Tissue culture of cat whiskers is a method in plant micropropagationn. However, there is still an obstacle in sinensetin production due to a difficulty to obtain pure sinensetin. In this mini review, development of embryogenic callus and direct organogenesis from leaf explant are described. Using this method, we could help of plant biotechnology to get sinensetin substance.
\end{abstract}

Keywords: Embryogenic callus; Shoot; Sinensetin; Biotechnology

\section{Introduction}

Cat whiskers (Orthosiphon stamineus) are commonly used as Java tea to treat kidney stones including a variety of angiogenesisdependent diseases such as tumorous edema, rheumatism, diabetic blindness and obesity [1].

Embriogenic callus is the formation of callus that could develop into somatic embryos. Supplementation of amino acid, namely proline is necessary for the embryogenic callus formation. Mariani [2] used proline for somatic embryogenesis of rice.

Direct organogenesis is the formation of shoot from explant, such as leaf. Balance of auxin and cytokinins is a prerequisite for its process. Leaf age affect the process as well.

According to Yam [3], Orthosiphon stamineus extracts contain three flavonoids [3] as bioactive substances. Another secondary metabolite, namely osmarinic acid was reported by [4]. They found that the time of harvesting the plant cells from the culture medium affected the production of rosmarinic acid in cell cultures.

\section{Induction}

\section{The role of auxin}

For embryogenic callus initiation, 50micro molar 2, 4-D was used. The embryogenic calli were sub cultured on a monthly basis on the same medium with decreasing the concentration of 2, 4-D to 10 micromolar 2,4 -D [5]. In our study, embryogenic callus of 2, 4-D was induced with 2 ppm of 2, 4-D. Figure 1 shows the embryogenic callus of cat whiskers.

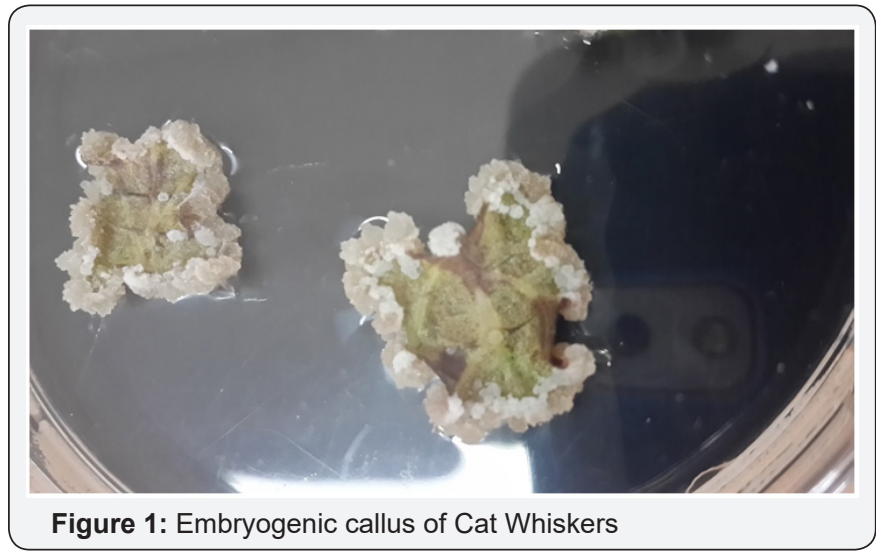

\section{Physiological requirement}

The physiological requirement of inducing the embryogenic callus depends on age of explant. We used young leaves as the explant while Smiskova et al., 2005 used immature seeds for initiating the embryogenic callus of Schisandra chinensis. Mariani [2] reported that scutellum of immature zygotic embryo was very good for direct somatic embryogenesis in rice. It is due to there is storage accumulation of protein and starch in the scutellum.

Review about the somatic embryo was explained in Mariani [2]. Growth of embryo from leaf explant was also described in sugarcane by [6]. Supplementation of proline in medium helped 
growth of somatic embryo and embryogenic callus. Proline is amino acids that influence physiology of the explant.

In Direct organogenesis process, shoots developed directly on the leaf explant. Age of leaf influenced formation of shoot. Therefore, young leaf was used in this study. Figure 2 shows shoots of cat whiskers. Physiology of the leaf is the main factor. Rashid [7] reported indirect organogenesis from explant of nodal stem segment. In indirect organogenesis, shoot developed from callus. Direct organogenesis is preferred because it is without intervening of callus. Therefore, it could reduce soma clonal variation.

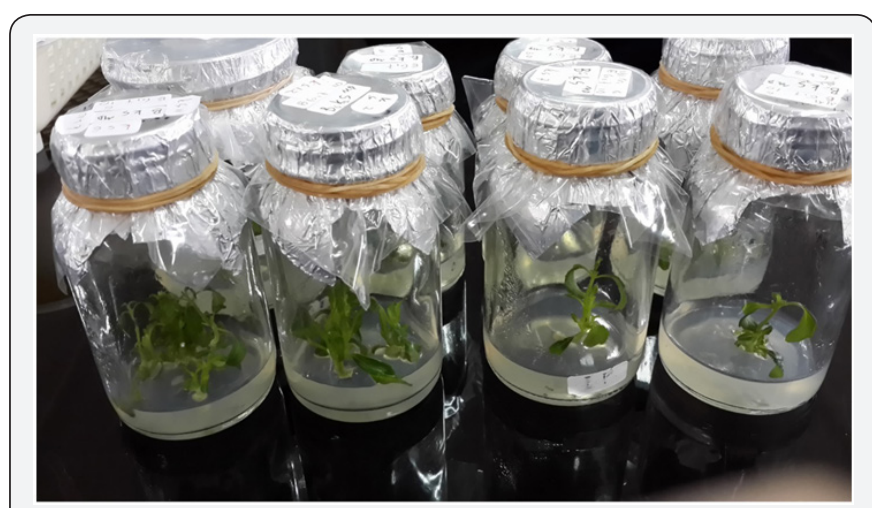

Figure 2: Shoots derived from leaf of Cat Whiskers

\section{Perspective and conclusion}

Two processes in tissue culture of Cat Whiskers have been described. These processes include embryogenic callus induction and direct organogenesis. For the future, tissue culture of cat whiskers (Orthosiphon stamineus) could be used for micro propagation and production of sinensetin in horticulture.

\section{Acknowledgement}

We thank for N. Heni Hanurati for assisting in tissue culture of cat whiskers.

\section{References}

1. Ahamed MB, Aisha AF, Nazzar ZD, Siddiqui, SM, Ismail Z, et al. (2012) Cat's whiskers tea (Orthosiphon stamineus) extract inhibits growth of colon tumor in nude mice and angiogenesis in endothelial cells via suppressing VEGFR prosphorylation. Nutr Cancer 64(1): 89-99.

2. Mariani TS, Miyake H, Takeoka Y (2000) Improvement of direct somatic embryogenesis in rice by selecting the optimal developmental age of explant applying desiccation treatment. Plant Production Science 3(2): 114-123.

3. Yam MF, Mohamed EA, Ang LF, Pei L, Darwis Y, et al. (2012) A simple isocratic HPLC method for the simultaneous determination of sinensetin, eupatorin and 3' hydroxy- 5,6,7,4-tetra methoxyflavone in Orthosiphon stamineus extracts. J. Acupunct Meridian stud 5(4):176182.

4. Liang LF, Keng CL, Lim BP, Weathers PJ (2006) Selection of cell lines for the production of rosmarinic acid from cell suspension cultures of Orthosiphon stamineus benth. In vitro cellular \& developmental biology-plant 42(6):518-542.

5. Smiskova A, Vlasinova H, Havel L (2005) Somatic embryogenesis from zygotic embryos of Schisandrachinensis. Biologia plantarum 49(3): 451-454.

6. Ho WJ, Vasil IK (1983) Somatic embryogenesis in Sugarcane (Saccharum officinarum L.): Growth and Plant Regeneration from Embryogenic Cell Suspension Cultures. Ann Bot 51: 719-729.

7. Rashid K, Nezhadahmadi A, Mohsin R, Azhar S, Efzueni S (2012) In vitro propagation of medicinal plant Orthosiphon stamineus (Misaikucing) through axillary branching and callus culture. Life Science Journal 9(4): 5283-5294.
This work is licensed under Creative Commons Attribution 4.0 License DOI: 10.19080/JOJHA.2018.01.555553

\section{Your next submission with Juniper Publishers will reach you the below assets}

- Quality Editorial service

- Swift Peer Review

- Reprints availability

- E-prints Service

- Manuscript Podcast for convenient understanding

- Global attainment for your research

- Manuscript accessibility in different formats

( Pdf, E-pub, Full Text, Audio)

- Unceasing customer service

Track the below URL for one-step submission https://juniperpublishers.com/online-submission.php 